Tor Atle Rosness (f. 1976) er medisinsk redaktør i Tidsskriftet, sykehjemslege i Bærum kommune og førsteamanuensis ved Lovisenberg Diakonale Høgskole.

Det er et privilegium å jobbe med eldre, men for å kunne gjøre en god jobb, trenger sykehjemsleger et godt kollegialt samarbeid

\section{De ensomme legene}

Sykehjemsansatte, det være seg leger eller annet helsepersonell, trenger generelt mer kompetanse. Legeforeningens landsstyre vedtok derfor i 2011 å opprette et kompetanseområde i alders- og sykehjemsmedisin (1). Bakgrunnen var behovet for å sikre bedre helsetjenester for pasienter i sykehjem og vekke interessen for faget sykehjemsmedisin. Tatt $\mathrm{i}$ betraktning det store antall leger $\mathrm{i}$ alle landets kommuner som arbeider innen dette fagfeltet, er det lite inspirerende at det per oktober 2015 kun er 27 leger som så langt er godkjent i kompetanseområdet og at alle disse godkjenningene er fra 2013 og 2014 (1). Mye tyder på at fagområdet fortsatt har lav status hos legene, slik det har vært antydet tidligere (2). Legeforeningen får også ofte høre at leger ikke ønsker å jobbe i sykehjem (3). Men det finnes heldigvis ildsjeler som omtaler legearbeidet i sykehjem som givende og spennende (4).

Eldre i sykehjem trenger nemlig dedikerte, fagsterke og engasjerte leger - som de trenger god kompetanse hos alle faggrupper. Hvis de andre ansatte er lite kvalifiserte, ufaglærte eller mangler gode norskferdigheter (5-7), blir det enda mindre attraktivt å være sykehjemslege. Selv om jobb i sykehjem innebærer fleksibel arbeidstid, lite eller ingen vaktbelastning og god lønn, er det ikke overraskende at leger tenker på andre karrieremuligheter.

Hverdagen for sykehjemslegen kan være ensom. Dette har flere grunner. Det er en påkjenning å være eneste lege på huset, ofte ansatt i lav stillingsbrøk og med medisinsk ansvar for skrøpelige eldre. Særlig belastende er det når det er knapt med tid til hver enkelt av dem. Sykehjemspasienter har ifølge en norsk studie fra Bergen i gjennomsnitt syv ulike diagnoser som krever tett oppfølging og vel begrunnet behandling (8). Når pasienter legges inn i sykehjem med en lang liste av diagnoser, som hjertesvikt, alvorlig nyresvikt, hypertensjon, atrieflimmer, kols, uspesifisert kognitiv svikt, diabetes og tykktarmskreft, stilles det store krav til den som skal ha det medisinske ansvaret.

Optimal behandling i sykehjem bidrar til god livskvalitet for pasientene og kan gi en verdig avslutning på livet. Men siden eldre i sykehjem hyppig er utsatt for fall, infeksjoner, delir og forverring av kroniske lidelser, kan et slikt mål være vanskelig å oppnå (8). Sykehjemsleger må regelmessig ta stilling til hvorvidt pasienter skal sendes til sykehus ved for eksempel hjerte- eller nyresvikt eller forbli i kjente omgivelser med lindrende behandling. Eller om pasienter med alvorlig grad av demens og svelgevansker bør få antibiotika intravenøst ved lungebetennelse. Slike problemstillinger er det viktig å drøfte med kolleger på sykehuset, både for å forsikre seg om at man tar det rette valget og for å ha noen å dele ansvaret for den videre behandlingen med. Mange steder blir pasienter overflyttet fra sykehus til sykehjem så å si uten forvarsel, i marginal tilstand og med mangelfulle opplysninger i epikrisen. I slike tilfeller er det håpløst for sykehjemslegen - man vet ikke hvordan andre kolleger har vurdert situasjonen. Et potensielt fruktbart samarbeid mellom primær- og spesialisthelsetjenesten forblir uutnyttet.
Det er ofte sykehjemslegens ansvar å sette seg ned med pasienten og de nærmeste pårørende og informere om langtidsutsiktene på en tillitvekkende måte. Å forutsi sykdomsforløpet til en pasient, enten det dreier seg om en uke, en måned eller et år, er en sammensatt medisinsk oppgave, men kanskje særlig for sykehjemslegen er evnen til å tenke langsiktig og unngå medikamentell brannslukking viktig $(9,10)$. Et godt, men tilsynelatende lite brukt hjelpemiddel for langsiktig tenkning er anvendelse av en enkel graf. X-aksen representerer tid og $\mathrm{y}$-aksen en samlet klinisk vurdering av pasientens somatiske og kognitive funksjonsnivå. Kurven bøyer av nedover med stigende alder, men er ikke like bratt for alle. Opprettholdelse av livskvalitet og verdighet samt fysisk aktivitet, nødvendige medisiner og god pleie og omsorg gjør at kurven flater ut.

Økt kompetanse kun hos sykehjemslegene gir ikke nødvendigvis bedre behandling av den enkelte pasient. Legen er avhengig av observasjoner gjort av sykehjemmets øvrige helsepersonell. Det er derfor helt avgjørende at disse er kompetente nok til å kunne rapportere om endringer i pasientens tilstand. Et godt tverrfaglig samarbeid mellom leger, sykepleiere, ergoterapeuter og fysioterapeuter, der kortsiktige og langsiktige behandlingsstrategier drøftes under legevisitten, er god bruk av sykehjemmets ressurser. Etter en slik felles gjennomgang av pasientens tilstand kan sykehjemslegen danne seg et solid grunnlag for å be om videre råd fra spesialisthelsetjenesten.

Bedre helsetjenester for eldre i sykehjem kan ikke oppnås av sykehjemslegene alene. Et godt kollegialt samarbeid med leger ved sykehus og annet helsepersonell på sykehjem er avgjørende for å kunne lykkes. Ingen lege ønsker å stå som ansvarlig når en eldre sykehjemspasient får en uverdig avslutning på livet eller å ha dårlig samvittighet fordi det ikke var mulig å tilby optimal behandling. Ensomhet på sykehjemmet må forebygges. Sykehjemsmedisinen trenger flere ildsjeler - la det være en oppfordring!

\section{Litteratur}

1. Godkjente i kompetanseområdet i alders- og sykehjemsmedisin.

http://legeforeningen.no/Utdanning/Kompetanseomrader/Kompetanseomradei-alders-og-sykehjemsmedisin/Godkjente-i-kompetanseomradet-i-alders--ogsykehjemsmedisin/ (18.1.2016)

2. Eldre er lavstatus for leger. www.aftenposten.no/meninger/ Eldre-er-lavstatus-for-leger-6617516.html (18.1.2016).

3. Kvanvik M. Vil jobbe med sykehjemsmedisin. Tidsskr Nor Lægeforen 2012; 132: 721.

4. Kongsvik L. Sykehjemslege: dager med spenning og mange utfordringer. Tidsskr Nor Legeforen 2014; 134: 899.

5. Skremmende ordning. www.aftenposten.no/meninger/debatt/ Skremmende-ordning-7655377.html (18.1.2016).

6. Mange ufaglærte på sykehjem i Oslo. www.nsf.no/vis-nyhet/266903/ Mange-ufaglaerte-paa-sykehjem-i-Oslo (18.1.2016).

7. Språkvansker fører til alvorlige avvik på sykehjemmene. www.nrk.no/livsstil/ sprakvansker-skaper-sykehjemsavvik-1.8055059 (18.1.2016).

8. Bollig G, Husebø BS, Husebø S. Vakttjeneste for leger på sykehjem. Tidsskr Nor Legeforen 2008; 128: 2722-4

9. Janbu T. Sykehjem, omsorg og legehjelp. Tidsskr Nor Lægeforen 2007; 127: 2293. 10. Bruserud $\emptyset$. Best behandling i sykehjem. Tidsskr Nor Legeforen 2015; 135: 18. 